\section{Impact of Monetary Policy and Foreign Direct Investment Against Indonesia's Economic Growth}

Faridsky', Syarwani Canon², Boby Rantow Payu ${ }^{3}$

${ }^{1}$ Economic Faculty, Universitas Negeri Gorontalo, Indonesia

${ }^{2}$ Economic Faculty, Universitas Negeri Gorontalo, Indonesia

${ }^{3}$ Economic Faculty, Universitas Negeri Gorontalo, Indonesia

Email: galahad.kaligis@gmail.com

Abstract: This study aims to determine the impact of monetary policy and FDI on economic growth and discuss it. The monetary indicator variables used are inflation, interest rates and exchange rates. The data used in this study are secondary data in 1990-2019 sourced from data from the Central Bureau of National Statistics and the World Bank. The analysis model in this study uses Multiple Linear Regression with the Error Correction Model (ECM) analysis model. The results of the analysis show that in the long term monetary variables (inflation, interest rates and exchange rates) have a significant effect on economic growth. And in the short term FDI has a significant effect on economic growth. It is concluded that monetary variables (inflation, interest rates and exchange rates) are the main variables that affect economic growth in the long and short term.

Keywords: Monetary Policy; Inflation; Interest Rates; FDI
Article History:

Received on 10 Jan 2022

Revised on 12 Jan 2022

Accepted on 15 Jan 2022

Doi: 10.37479

Indexing:

Google Scholar; Asean

Citation

Index; Copernicus; SINTA

5 (Science And

Technology Index)

The journal allows the authors to hold the copyright without restrictions and allow the authors to retain publishing rights without restrictions. international license.

\title{
INTRODUCTION
}

Economic growth is a long-term problem that becomes a benchmark in measuring the progress and stability of a country's economy. Almost all countries, both developed and developing countries, face problems in maintaining stability and problems with their country's economic growth, with various factors affecting economic growth, including Capital, Labor, Technology and Social Systems.

Stable economic growth is a prerequisite for the success of a country's development, especially for developing countries. Improving people's welfare as measured by national income as a proxy for a country's economic growth is the goal of every country's economy. The approach commonly used in measuring national income is Gross Domestic Product, by calculating the value of goods and services (output) produced by a country's economy in a 1 year period.

GDP as a tool used to measure income and expenditure in the economy during a certain period. The GDP value used is GDP based on constant prices (real GDP) so that the resulting growth is growth that occurs due to additional production. In the economy, there is a need for a balance that is the target for improving the economy of a country. This can be achieved through the involvement of economic variables that affect the balance.

The central bank (BI) in this case as the monetary authority in promoting high economic growth in a sustainable manner seeks to regulate the balance between the stability of the value of the rupiah against goods and services and the stability of the rupiah against other countries.

The stability of a country's economy can support economic growth in that country. One indicator to improve economic stability is by looking at macroeconomic performance, including interest rates, exchange rates, inflation and investment. 
In this regard, one of the policies used to improve and maintain the stability of Indonesia's economic growth is monetary policy. Monetary policy is one of the policies used to overcome economic problems with the main objective of maintaining stability in the value of the rupiah. This policy also regulates the course of the economy, especially the macro economy so that it can run as expected with several monetary policy instruments that have been determined by policy makers.

Monetary policy can be said to be a policy relating to the control of financial institutions, the active sale and purchase of securities by the monetary authority as the effect of changing the state of money and the passive buying and selling of securities arising in an effort to maintain certain interest rates, stock price stability, or to fulfill certain other obligations (Jhingan 2000).

The effect of monetary policy on economic growth and changes in economic activity in general depends on the implementation of monetary policy and the central bank in choosing the right monetary tool to formulate monetary policy for macroeconomic objectives (Alavinasab 2016).

Regarding economic growth in Indonesia, based on Figure 1, the economic conditions of countries in Southeast Asia have grown steadily and have always been at 6 percent during 2015-2019 compared to Indonesia, and Cambodia has even stabilized at 7 percent over the last 5 years. In general, the economy of several Southeast Asian countries grew steadily, but the national economy had not been able to grow to 6 percent, even though various efforts and policies had been carried out by the government, both in terms of fiscal and monetary terms, in order to increase Indonesia's economic growth.

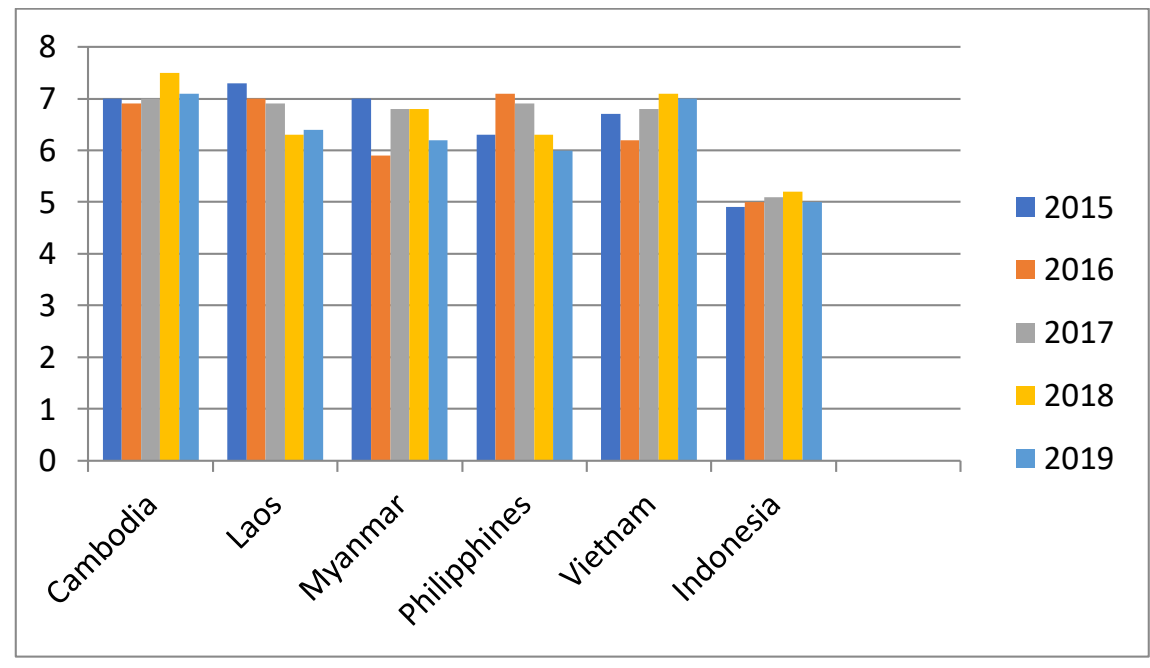

Figure 1. Economic Growth in Several Southeast Asian Countries 2015-2019 (Source: Central Bureau of Statistics 2019)

For Indonesia itself, Indonesia's economic growth in 2018 was the highest in the last five years, which was 5.17 percent. When compared from the previous year, the Indonesian economy was only 5.03 percent in 2016 and 5.07 percent in 2017. However, this did not make Indonesia's economic growth continue to accelerate to 6 percent, and even decreased again in 2019 by 5.02 percent. Based on the table data above, Indonesia's economic growth rate tends to stagnate at the position of $5 \%$, of course this achievement is still far from the expectations that Indonesia wants to achieve as a developed country.

Bank Indonesia as the monetary authority in Indonesia has made various efforts to promote the stability of the Indonesian economy so that it continues to grow well, with the implementation of the ITF (Inflation Targeting Framework) monetary policy in which inflation is the main target. In the data table below, inflation growth in Indonesia is still relatively well maintained, and Indonesia's economic growth should also be able to increase to $6 \%$, but in fact Indonesia's economic growth has not experienced a significant increase.

Table 1. Trend of Monetary Variables and Indonesia's Economic Growth Period 2014-2018

\begin{tabular}{|l|c|c|c|c|c|}
\hline & 2014 & 2015 & 2016 & 2017 & 2018 \\
\hline M2 (Milyar) & $4,173.33$ & $4,548.80$ & $5,004.98$ & $5,419.17$ & $5,760.05$ \\
\hline M1 (Milyar) & 942.22 & $1,055.43$ & $1,237.64$ & $1,390.80$ & $1,457.01$ \\
\hline Tingkat Suku Bunga (Persen) & 7.75 & 7.51 & 7.25 & 4.25 & 6.01 \\
\hline Nilai Tukar (IDR/\$) & 12,388 & 13,788 & 13,473 & 13,555 & 14,39 \\
\hline
\end{tabular}




\begin{tabular}{|l|c|c|c|c|c|} 
Penyaluran Kredit I(Milyar) & 115,015 & 141,091 & 109,821 & 115,332 & 72,913 \\
\hline Inflasi(Persen) & 8.36 & 3.35 & 3.02 & 3.61 & 3.13 \\
\hline Pertumbuhan Ekonomi (Persen) & 5.02 & 4.88 & 5.02 & 5.07 & 5.17 \\
\hline
\end{tabular}

Source: Bank Indonesia (2019)

If you look at the data above, this illustrates that there are still macroeconomic problems that have not been able to be resolved, such as sharp unemployment and poverty rates, exchange rate crises against foreign debt, inflation and lack of competitiveness that have caused instability in the Indonesian economy. Thus the question arises whether there is something wrong with the policies issued by the government, because the policies issued have been designed as well as possible to encourage economic growth, but economic growth is still stagnant at 5 percent. In general, there are four macroeconomic problems, namely: the level of aggregate prices (inflation), the level of output (GDP), employment (employment) and the balance of payments (BOP). The four problems can be influenced by the government through fiscal and monetary policies.

According to Adiningsih (2005), the Indonesian economy has been moving in the right direction since 2000 or two years after the 1998 economic crisis. Since then, Indonesia has experienced moderate and stable economic growth. The new government under President Susilo Bambang Yudhoyono has given priority to higher economic growth and job creation through investment.

Based on the theory of economic growth developed by Robert Solow with the Neo-Classical approach, capital formation and population growth are factors that have a significant effect on the economic growth of a country. In this case, the role of both domestic and foreign investment through foreign direct investment (FDI) contributes to economic growth. FDI, capital, and labor are important factors in the process of economic growth.

Foreign Direct Investment (FDI) is a form of investment that is invested directly and is engaged in various fields. The flow of Foreign Direct Investment (FDI) does not include global portfolio investments in the form of stocks through the sale and purchase of stock exchanges, bonds and other securities. Capital inflows from abroad can be divided into three, namely foreign debt, portfolio investment and foreign direct investment (FDI). Regional development is an internal part of national development, and takes place in a sustainable manner. Development aims to improve the welfare of the community, one of which is an important area of economic development. (Kurniawan, 2017)

FDI (Foreign Direct Investment) has a big role in the process of Indonesia's economic growth. FDI (Foreign Direct Investment) increases production and technology capabilities from abroad to enter the country. The presence of foreign investment in the form of Foreign Direct Investment (FDI) can increase the competitiveness and excellence of domestic products (Jufrida, 2016). Foreign Direct Investment (FDI) is very helpful for Indonesia in carrying out national development.

Table 3. Foreign Direct Investment (FDI) Inward Flows to ASEAN 2010-2019

\begin{tabular}{|l|c|c|c|c|c|c|c|c|c|c|}
\hline Host Country & 2010 & 2011 & 2012 & 2013 & 2014 & 2015 & 2016 & 2017 & 2018 & 2019 \\
\hline Brunei Darussalam & 625.4 & $1,208.3$ & 864.8 & 725.5 & 568.2 & 171.3 & -1504 & 460.1 & 517.3 & 374.6 \\
\hline Cambodia & 782.6 & 891.7 & $1,557.1$ & $1,274.9$ & $1,726.5$ & $1,701.0$ & $2,279.7$ & $2,732.2$ & $3,102.6$ & $3,663.0$ \\
\hline Indonesia & $13,770.2$ & $19,241.6$ & $19,137.9$ & $18,443.8$ & $21,810.4$ & $16,642.1$ & $3,920.7$ & $20,579.2$ & $20,563.5$ & $23,943.2$ \\
\hline Laos PDR & 332.6 & 466.8 & 294.4 & 426.7 & 913.2 & $1,079.2$ & $1,075.7$ & $1,695.4$ & $1,358.0$ & 755.5 \\
\hline Malaysia & $9,155.9$ & $12,000.9$ & $9,400.0$ & $12,107.1$ & $10,875.3$ & $10,180.0$ & $11,290.3$ & $9,295.8$ & $7,611.3$ & $7,698.0$ \\
\hline Myanmar & $2,248.8$ & $2,058.2$ & $1,354.2$ & $2,620.9$ & 946.2 & $2,824.5$ & $2,989.5$ & $4,002.4$ & $1,609.8$ & $1,729.9$ \\
\hline Philippines & $1,298.0$ & $1,815.9$ & $2,797.0$ & $3,859.8$ & $5,814.6$ & $5,639.2$ & $8,279.5$ & $10,256.4$ & $9,948.6$ & $7,685.3$ \\
\hline Singapore & $57,460.6$ & $39,886.6$ & $60,101.9$ & $56,670.9$ & $73,284.5$ & $59,702.3$ & $68,820.0$ & $83,618.3$ & $79,723.1$ & $92,078.2$ \\
\hline Thailand & $14,746.7$ & $2,473.7$ & $12,899.0$ & $15,936.0$ & $4,975.5$ & $8,927.6$ & $3,486.2$ & $8,285.2$ & $13,186.3$ & $4,816.6$ \\
\hline Vietnam & $8,000.0$ & $7,519.0$ & $8,368.0$ & $8,900.0$ & $9,200.1$ & $11,800.0$ & $12,600.0$ & $14,100.0$ & $15,500.0$ & $16,120.0$ \\
\hline \multicolumn{1}{|c|}{ ASEAN } & $108,420.7$ & $87,562.0$ & $116,774.3$ & $120,965.5$ & $130,114.5$ & $118,667.1$ & $114,591.1$ & $155,025.0$ & $153,120.4$ & $158,864.4$ \\
\hline \multicolumn{7}{r}{ Source: National BPS and Asean Statistics $(2020)$} & &
\end{tabular}

From the table above, it can be seen that FDI in Indonesia continues to increase from year to year, ranking second after Singapore, compared to other Southeast Asian countries. However, this is not in line with Indonesia's economic growth, which from year to year is still in the 5 percent position, where FDI should be expected to be able to boost Indonesia's economic growth rate.

In maintaining the stability and economic growth of a country, there are many ways that the country does, especially developing countries in increasing the economic growth of their country. including overall economic development both from infrastructure, technology, labor and so on. This of course requires a large source of capital. To get large capital, a country must attract foreign investors into their country in order to invest their capital in the country, so that it can increase the country's economic growth with various profitable aspects. 
However, Indonesia has not been able to increase its economic growth above 6 percent even though various policies have been carried out including monetary and fiscal as well as foreign investment. go hand in hand causing inequalities that must be resolved. This is a challenge for Indonesia to achieve national development goals and the welfare of the Indonesian people.

\section{METHODOLOGY}

This research consists of 3 important points in the economy, namely monetary policy, foreign investment, and economic growth in Indonesia in the last 30 years (1990-2019). The design of this research is a research with a quantitative approach, namely a research method based on the philosophy of positivism. Where population data or certain samples are used in data collection, by conducting research or analysis starting from interpretation and getting the results. Quantitative analysis is used to test the established hypotheses. With the aim of drawing conclusions on the results of the study and knowing the influence between two or more variables. This study uses quantitative data. Quantitative data is a type of data that is measured or calculated directly or in the form of information expressed in the form of numbers obtained from various Central Statistics Agency (BPS), BKPM, World Bank, and other sources. Data is also supplemented from library sources and other related literature. The types of data used are monetary policy (inflation, interest rates, exchange rates), foreign direct investment (FDI) and economic growth. The analysis model in this study uses Multiple Linear Regression with the Error Correction Model (ECM) analysis model. This analysis aims to solve the problem of data that is not stationary in a time series (Time series) and to find out the long-term and short-term relationships of the dependent and independent variables. In the ECM model, several steps are used, namely the stationary data test, the cointegrity test, and the ECM test.

\section{RESULTS}

Data Stationery Test

Table 1. Individual Unit Root Test (Level)

Null Hypothesis: Unit root (individual unit root process)

Series: PE, INF, RATE, EXCHANGE, FDI

Sample: 19902019

\begin{tabular}{ccc}
\hline \hline Method & Statistic & Prob.** \\
\hline \hline ADF - Fisher Chi-square & 54.6817 & $0.0000^{* * *}$ \\
\hline \hline Intermediate ADF test results TABULASI \\
\hline \hline Series & Prob. \\
\hline PE & $0.0001^{* * *}$ \\
INF & $0.0022^{* * *}$ \\
RATE & $0.0001^{* * *}$ \\
EXCHANGE & $0.2286^{\mathrm{NS}}$ \\
FDI & $0.2608^{\mathrm{NS}}$ \\
\hline \hline
\end{tabular}

Based on the table above, it is known that most of the variables are not stationary at the level level. Only the variables of economic growth, inflation and rate are stationary, while the variables of exchange and FDI are not stationary. Therefore, for the purposes of ECM regression, it is necessary to carry out a differentiation process for the data so that the data is stationary at the same degree. With the same procedure as the steps above, the results of the ADF root test at the first difference degree are as follows:

Table 2. Individual Unit Root Test (First Difference)

Null Hypothesis: Unit root (individual unit root process)

Series: PE, INF, RATE, EXCHANGE, FDI

Sample: 19902019

\begin{tabular}{ccc}
\hline Method & Statistic & Prob.** \\
\hline \hline ADF - Fisher Chi-square & 107.634 & $0.0000^{* * *}$ \\
\hline \hline Intermediate ADF test results D(TABULASI) \\
\hline \hline Series & Prob. \\
\hline D(PE) & $0.0000^{* * *}$ \\
D(INF) & $0.0000^{* * *}$ \\
D(RATE) & $0.0000^{* * *}$ \\
D(EXCHANGE) & $0.0018^{* * *}$ \\
D(FDI) & $0.0003^{* * *}$ \\
\hline \hline \multicolumn{2}{c}{ Source: Data Processed (2021) }
\end{tabular}


The results of the Dicky Fuller Single Root (ADF) test for the first degree difference show that all data are defined at the same level, namely the first difference. After the data is stationary with a single root test and the degree of integration of the first difference, the next step is to conduct a joint test (cointegration) to determine the longterm measurement.

\section{Cointegration Test}

\section{Table 3. First Condition}

Null Hypothesis: RES has a unit root

Exogenous: Constant

Lag Length: 0 (Automatic - based on SIC, maxlag=2)

\begin{tabular}{ccc}
\hline & t-Statistic & Prob. $^{*}$ \\
\hline \hline Augmented Dickey-Fuller test statistic & -4.851674 & $0.0005^{* * *}$ \\
\hline Source: Data Processed (2021)
\end{tabular}

Table 4. Second Condition

Augmented Dickey-Fuller Test Equation

Dependent Variable: D(RES)

Method: Least Squares

Sample (adjusted): 19912019

Included observations: 29 after adjustments

\begin{tabular}{ccccc}
\hline \hline Variable & Coefficient & Std. Error & t-Statistic & Prob. \\
\hline \hline RES $(-1)$ & -0.946663 & 0.195121 & -4.851674 & $0.0000 * * *$ \\
\hline \hline & Source: Data Processed (2021)
\end{tabular}

Based on the two conditions above, the ADF test is known to be significant at the $1 \%$ level (First Condition is Fulfilled) and the Residual value has a negative coefficient of 0.946663 with a significant probability value at the $1 \%$ level (Second Condition is Fulfilled). This means that the value of the ADF and the residuals in the long-term equation is stationary at the first difference because the ADF statistic is absolutely smaller than the critical value (Probability) either at $1 \%, 5 \%$ or $10 \%$ or seen from the probability that is in the residual root test. ADF Statistics $=0.0003$ and the estimated probability of $A D F=0.0000$. So that the ECM model can be continued.

\section{Estimated ECM (Error Correction Model) Model}

The ECM model used in this study is the Engle-Granger ECM model. ECM is a statistical method used to find longterm and short-run equilibrium regression equations based on non-stationary data. The ECM calculation uses the residual value in the cointegration test as the error correction term.

\section{Table 4. Long-Term Estimation Results}

Dependent Variable: PE

Method: Least Squares

Included observations: 30

\begin{tabular}{crcrr}
\hline \hline Variable & Coefficient & Std. Error & t-Statistic & Prob. \\
\hline C & 5.953710 & 0.851514 & 6.991913 & $0.0000 * * *$ \\
INF & -0.245399 & 0.047962 & -5.116557 & $0.0000^{* * *}$ \\
RATE & 0.115617 & 0.066157 & 1.747619 & $0.0928^{*}$ \\
EXCHANGE & 4375.403 & 2156.360 & 2.029069 & $0.0532 *$ \\
FDI & 0.003937 & 0.241602 & 0.016295 & $0.9871^{\text {NS }}$ \\
\hline R-squared & 0.810872 & Akaike info criterion & 4.056111 \\
Adjusted R-squared & 0.780611 & Schwarz criterion & 4.289644 \\
Log likelihood & -55.84166 & Hannan-Quinn criter. & 4.130820 \\
F-statistic & 26.79636 & Durbin-Watson stat & 1.862593 \\
Prob(F-statistic) & $0.0000 * * *$ & & & \\
\hline \hline
\end{tabular}

Source: Data Processed (2021)

The table above is the result of long-term estimation in the ECM method, from the above estimation the regression equation is formed as follows:

$\mathrm{PE}_{\mathrm{t}}=5.953710-0.245399 \mathrm{INF}_{\mathrm{t}}+0.115617 \mathrm{RATE}_{\mathrm{t}}+4375403 \mathrm{EXCHANGE}_{\mathrm{t}}+0.003937 \mathrm{FDI}_{\mathrm{t}}$ 
Where, PE is the variable of economic growth, INF is the variable of Inflation, Rate is the variable of Interest Rate, Exchange is the variable of Rupiah Exchange Rate and FDI is Foreign Direct Investment. So that the interpretation of the estimation results in the form of a statement becomes as follows:

The variable of Economic Growth (PE) without being influenced by any independent variables in the research model (INF, RATE, EXCHANGE and FDI) will be worth 5.953710 percent.

Inflation variable (INF) has a negative effect on economic growth. This means that every 1 percent increase in inflation will reduce economic growth by 0.245399 percent.

Variable Interest Rate (RATE) has a positive effect on economic growth. This means that every 1 percent increase in interest rates will increase economic growth by 0.115617 percent.

The Rupiah Exchange Rate (EXCHANGE) variable has a positive effect on economic growth. This means that the weakening of the Rupiah Exchange Rate by 1 per USD will increase economic growth by 4375,403 percent.

Variable Foreign Direct Investment (FDI) has a positive effect on economic growth. This means that every increase in Foreign Direct Investment by 1 billion Rupiah will increase economic growth by 0.003937 Percent.

\section{Table 5. Short-Term Estimation Results}

Dependent Variable: $\mathrm{D}(\mathrm{PE})$

Method: Least Squares

Sample (adjusted): 19912019

Included observations: 29 after adjustments

\begin{tabular}{crrrr}
\hline \hline Variable & Coefficient & Std. Error & t-Statistic & \multicolumn{1}{c}{ Prob. } \\
\hline C & -0.119103 & 0.503156 & -0.236713 & $0.8149^{\mathrm{NS}}$ \\
D(INF) & -0.223195 & 0.068622 & -3.252546 & $0.0034^{* * *}$ \\
D(RATE) & 0.208871 & 0.057272 & 3.647009 & $0.0013^{* * *}$ \\
D(EXCHANGE) & -53.63990 & 17421.82 & -0.003079 & $0.9976^{\mathrm{NS}}$ \\
D(FDI) & 0.484910 & 0.468477 & 1.035078 & $0.3110^{\text {NS }}$ \\
RES(-1) & -0.999543 & 0.204102 & -4.897275 & $0.0001^{* * *}$ \\
\hline R-squared & 0.857942 & Mean dependent var & -0.076552 \\
Adjusted R-squared & 0.834266 & S.D. dependent var & 5.309950 \\
S.E. of regression & 2.161703 & Akaike info criterion & 4.535255 \\
Sum squared resid & 112.1510 & Schwarz criterion & 4.770996 \\
Log likelihood & -60.76120 & Hannan-Quinn criter. & 4.609086 \\
F-statistic & 36.23641 & Durbin-Watson stat & 2.549429 \\
Prob(F-statistic) & $0.0000 * * *$ & & & \\
\hline \hline
\end{tabular}

Source: Data Processed (2021)

The table above is the result of long-term estimation in the ECM method, from the estimation above the regression equation formed is as follows

$$
\begin{aligned}
& \mathrm{D}\left(\llbracket P E \rrbracket \_t\right)=-0.119103-0.223195 \mathrm{D}\left(\llbracket \mathrm{INF} \rrbracket \_\mathrm{t}\right)+0.208871 \mathrm{D}\left(\llbracket R A T E \rrbracket \_t\right)-53.63990 \mathrm{D}\left(\llbracket E X C H A N G E \rrbracket \_(t\right. \\
& ))+0.484910\left[\text { [D(FDI } \ \_t\right)-0.999543 \operatorname{RES}(-1)
\end{aligned}
$$

It means:

Changes in the correction of economic growth variables without being influenced by changes in corrections between inflation, rate, Exchange and FDI variables, the changes in the correction of economic growth variables have a constant value of 0.050738 percent.

Changes in the correction of the inflation variable ( $D * I N F)$ have a negative effect on changes in the correction of the economic growth variable (D*PE). This means that if the correction of the inflation variable changes by 1 percent, it will decrease the correction of the economic growth variable by 0.223195 percent.

Changes in the correction of the Interest Rate ( $D *$ RATE) variable have a positive effect on changes in the correction of the economic growth variable. This means that if the correction of the Rate variable has increased by 1 percent, it will increase the correction of changes in the economic growth variable by 0.208871 percent.

Changes in the correction of the Rupiah Exchange Rate (D*EXCHANGE) variable have a negative effect on changes in the correction of economic growth variables. This means that if the correction of the Rupiah Exchange Rate variable weakens by 1 USD/Rp, it will reduce the correction for changes in the economic growth variable by 53.63990 percent. 
Changes in the correction of Foreign Direct Investment (D*FDI) variables have a positive effect on changes in the correction of economic growth variables. This means that if the correction of the Foreign Direct Investment variable increases by 1 billion Rupiah, it will increase the correction for changes in the economic growth variable by 0.484910 percent.

Residual (Res) has a negative coefficient on the correction of changes in economic growth variables. This means that the correction of changes in economic growth variables with their balance values will be adjusted within 1 year (rounded up from 0.999543).

\section{Coefficient of Determination}

The value of $\mathrm{R} 2$ is close to 1 or greater than 0.5 then, the independent variable provides all the information needed to predict the dependent variable. Conversely, the smaller the value of $\mathrm{R}$ Square, the more limited the ability of the independent variable to explain the variation of the dependent variable.

The value of $\mathrm{R}$ Square has a weakness, because the value of R2 increases with each additional independent variable, even if the independent variable does not significantly affect the dependent variable. Therefore, in looking at the coefficient of determination, the adjusted value of R2 is used.

It is known, the value of Adj R2 in the long term is 0.780611 , if this value is presented it becomes $78.06 \%$. That is, the independent variable in the model can explain the variation of the dependent variable by 78.06 percent. And the remaining $21.94 \%$ is explained by other variables outside of observations.

Meanwhile, for the short term, the value of Adj R2 is 0.834266 , if this value the percentage becomes $83.42 \%$. This means that the independent variable and the model can explain the variation of the dependent variable by $83.24 \%$. and the remaining $16.58 \%$ can be explained by other variables outside the observation model.

\section{F Test}

Simultaneous test or $\mathrm{F}$ test is a test conducted to determine whether the independent variable and the dependent variable have a significant effect at the same time. The estimation results show that the value of the probability of the statistical $F$ value in the long-term and short-term model is 0.0000 this value when compared to the value of the significant level $(1 \%, 5 \%$ and $10 \%)$, so the decisions that can be taken that simultaneously affect the economic growth.

\section{DISCUSSION}

\section{The Effect of Inflation on Economic Growth}

From the results of long-term regression analysis, it is known that the inflation variable has a negative effect and can be explained significantly to economic growth during the period 1990-2019 with a negative coefficient value of 0.245399 . This means that every 1 percent increase in the inflation variable will increase economic growth by 0.245399 percent. The same thing happens in the short-term estimation, it is known that the correction of changes in inflation variables has a negative effect and can be explained significantly to the correction of changes in economic growth variables during the period 1990-2019 with a negative coefficient value of 0.223195 . This means that each change in the correction of the inflation variable by 1 percent will decrease the change in the correction in the economic growth variable by 0.223195 percent.

In simple terms, on the other hand, if inflation decreases, economic growth will increase. Inflation is the process of increasing the price of goods and services from time to time. High and low inflation also raises and lowers the level of production. Keynes's theory says that inflation occurs because people want to live beyond the limits of their economic capacity, so nowadays people are more concerned with quality than quantity. Keynes also argues that a lower inflation rate will encourage entrepreneurs to invest in capital and employ more people, boosting employment and restoring economic growth (Qoyum et al, 2021). As a result of inflation, which means a decrease in the purchasing power of a currency, the acceleration of the increase in the price of goods and services is relatively increasing every year. Thus, the ability of people with fixed incomes to meet their daily needs also decreases. Unstable inflation also disrupts trade, discourages people from saving, and many other negative impacts that are not good for the economy as a whole.

Indonesia is a country that has experienced inflation during the economic crisis in 97/98, where the increase in the price of goods experienced a fairly high trend that year. However, the increase in inflation did not have such a profound effect, this is indicated by only a few years after the slump caused by the economic downturn in Indonesia. Indonesia only takes 1 year to recover the economy in its region. Bank Indonesia also emphasized the importance of maintaining price stability. Low and stable inflation is a prerequisite for sustainable economic growth, which in turn will help improve people's welfare. The importance of controlling inflation lies in the fact that high and unstable inflation has a negative impact on the social and economic conditions of the community (Dewi, 2021). The results of this study are in line with research conducted by Sopian et al (2021) explaining that inflation has a negative effect on economic growth, this is because the high rate of inflation that occurs inhibits 
the ability of the community to develop economically and slows down economic development activities which ultimately results in a decline in economic growth.

\section{The Effect of Interest Rates on Economic Growth}

From the results of long-term regression analysis, it is known that the interest rate variable has a positive effect and can be explained significantly on economic growth during the period 1990-2019 with a coefficient value of 0.115617 . This means that every 1 percent increase in the Interest Rate variable will increase economic growth by 0.115617 percent. The same thing happens in the short-term estimation, it is known that the correction of changes in interest rate variables has a positive effect and can be explained significantly to the correction of changes in economic growth variables during the period 1990-2019 with a coefficient of 0.208871. This means that every 1 percent change in the correction of the Interest Rate variable will decrease the correction change in the economic growth variable by 0.208871 percent. In Keynes theory economic growth can be formed by consumption, investment, government spending and net exports. Keynes theory is very closely related to interest rates, it is based on the theory of investment and savings. This is also described in Sari's research (2020), The higher the interest rate, the greater the tendency of people to save or invest in securities, which means that a higher interest rate encourages people to stop consuming or reduce their spending. Therefore, they prefer to hold or invest in securities because they can benefit more from these high interest rates.

The above statement can be simplified in the case where if people hold back consumption and increase investment further when interest rates are low, then in a period of several years and sell them when interest rates increase. The same is true in the case when interest rates rise, economic activity implies an increase in factors of production. Why, this is due to the existence of a company's obligation to increase factors of production, by adding labor and investment. With this, the production of goods and services increases which directly implies that economic growth will also increase. The results of this study are in line with research conducted by Asnawi (2018) explaining that interest rates have a positive effect on economic growth, this is based on the fact that an increase in interest rates can increase the value of investment which is part of the components that make up economic growth.

\section{Effect of Exchange Rate on Economic Growth}

From the results of long-term regression analysis, it is known that the rupiah exchange rate variable has a positive effect and can be explained significantly on economic growth during the period 1990-2019 with a coefficient value of 4375,403 . This means that every increase in the rupiah exchange rate variable of $1 \mathrm{USD} / \mathrm{Rp}$ will increase economic growth by 4375,403 percent. While the short-term estimation, it is known that the correction of changes in the rupiah exchange rate variable has a negative effect and is not directly explained by the correction of changes in economic growth variables during the period 1990-2019 with a negative coefficient value of 53.63990. This means that every change in the correction increase in the rupiah exchange rate variable by 1 USD/Rp does not directly reduce the correction change in the economic growth variable by 53.63990 percent. Exchange rate is the activity of exchanging one currency for another in the foreign exchange market. Some economists believe that the US dollar exchange rate is a reliable benchmark against which to compare the value of currencies in developing countries. The rupiah exchange rate is closely related to exports and imports (Net Exports). In this case, Indonesia replaces the rupiah with the US dollar (United States) in international trade. Net exports are the constituent components of GDP and GDP is a measure of economic growth.

In the context of the rupiah exchange rate having a negative effect on economic growth, it can be explained that if the rupiah exchange rate weakens (depreciates) against the US\$, it can be ascertained that the price of domestic goods tends to be cheaper and foreign goods tend to be expensive. So that the public or the government mobilize relatively large funds in importing these goods if there is a depreciation of the Rupiah against the Dollar. Abdullah (2020) The depreciation of the Rupiah against the Dollar affects the quantity of net exports, this is because people do not find satisfaction in terms of the number of goods that can be imported or financial returns when exporting. This will increase the difference provided by net exports on economic growth. Meanwhile, Arfiani's research (2019) links the rupiah exchange rate and foreign debt to economic growth. Arfiani (2019) explained that the weaker the rupiah exchange rate (the rupiah depreciated against the dollar), the greater the debt burden. Of course, an increasing debt burden can hamper economic growth.

The results of this study are in line with research conducted by Wiriani (2020) explaining that the exchange rate has a negative effect on economic growth. This is because the higher the exchange rate or the weakening of the rupiah exchange rate affects the prices of goods, especially imported goods, if imported raw materials for domestic products rise, it will ultimately affect the price of goods and reduce economic growth.

\section{The Effect of Foreign Direct Investment on Economic Growth}

From the results of the long-term regression analysis, it is known that the variable Foreign Direct Investment (FDI) does not directly have a positive effect on economic growth during the period 1990-2019 with a positive coefficient value of 0.003937 . This means that every increase in the foreign direct investment variable of 1 billion Rupiah increases economic growth by 0.003937 percent, but this increase cannot be explained by the FDI variable. The same thing happens in the short-term estimation, it is known that the correction of changes in foreign direct investment variables does not directly have a positive effect on the correction of changes in 
economic growth variables during the period 1990-2019 with a Positive coefficient value of 0.484910 . This means that every change in the correction of the increase in the correction of the foreign direct investment variable by 1 billion rupiah does not directly increase the correction change in the economic growth variable by 0.484910 percent.

Foreign direct investment (FDI) is an investment in which a multinational company establishes a branch in another country of export destination to facilitate export and import activities and to save costs. We are far from pulling back several years by looking at the development of FDI in Indonesia with the problems that have occurred in this country. In Indonesia, the development of foreign investment is caused by various problems such as poor infrastructure, inefficient bureaucracy, limited budget access, unfavorable labor regulations, uncertain policies, inflation, corruption, excessive taxation, poor work ethic, etc. Then the economic crisis that occurred in mid-1997-1999 added to the problems of the economy in Indonesia, which experienced a decline in economic growth which was so high that it caused domestic investment to decline. Therefore, to cover the deficit, Indonesia needs foreign resources in the form of Foreign Investment (FDI), which is an external investment that can contribute to national financing and development.

However, FDI does not have a significant effect on economic growth in the long and short term. Because workers who do not have sufficient quality usually work with traditional tools which cannot increase agricultural productivity. Illiteracy makes it difficult for them to work in new science and technology. On the other hand, the introduction of new technologies into industry and industrial processes is sometimes capital intensive. As a result, unemployment has increased despite improvements in many sectors (Putri, 2018). The results of this study are in line with research conducted by Putri et al, (2018) which shows that foreign direct investment has a positive effect on economic growth. This is because FDI can stimulate economic growth in terms of improving the quality of existing resources by means of technological advances and good quality of labor.

\section{CONCLUSION}

Based on the results based on the results of the analysis and discussion of the analysis of the impact of monetary policy and foreign direct investment on Indonesia's economic growth for the period 1990-2019, it can be concluded as follows:

1. Inflation has a negative and significant effect in the long and short term on Indonesia's economic growth for the period 1990-2019

2. Interest rates have a positive and significant effect in the long and short term on Indonesia's economic growth for the period 1990-2019

3. Exchange rate has a positive and significant effect on economic growth in the long term. The exchange rate has a negative effect and is not statistically significant. This means that every time there is a depreciation of the exchange rate, economic growth will increase in the long term and decrease in the short term.

4. FDI has a positive effect in the long and short term. However, FDI in the long term and short term clearly explains that there is no significant effect between FDI on Indonesia's economic growth for the period 19902019.

\section{REFERENCES}

Amrini, Y., H. Aimon, and E. Syofyan. 2014. "Analisis Pengaruh Kebijakan Moneter Terhadap Inflasi Dan Perekonomian Di Indonesia." Jurnal Kajian Ekonomi 2(4): 102880.

Asafu-Adjaye, John. 2000. "The Effects of Foreign Direct Investment on Indonesian Economic Growth, 19701996." Economic Analysis and Policy 30(1): 49-62. http://dx.doi.org/10.1016/S0313-5926(00)50004-6.

C., Udude Celina. 2014. "Monetary Policy and Economic Growth of Nigeria ( 1981 - 2012 )." Journal of Policy and Development Studies 9(1): 234-47.

Darwanti, Dhenok, . Darman, and . Yolanda. 2021. "Contribution of Domestic Direct Investment and Direct Foreign Investment to Economic Growth in Indonesia Era Joko Widodo." International Journal of Business, Economics and Management 8(1): 39-49.

Dewi, Ernita, Syamsul Amar, and Efrizal Sofyan. 2013. "Jurnal Kajian Ekonomi, Januari 2013, Vol. I, No. 02 Analisis Pertumbuhan Ekonomi, Investasi, Dan Konsumsi Di Indonesia Oleh: Dewi Ernita * , Syamsul Amar **, Efrizal Syofyan ***." Jurnal Kajian Ekonomi I(02): 176-93.

Febriana, Asri, and Masyhudi Muqorobbin. 2002. "Investasi Asing Langsung Di Indonesia Dan Faktor Yang Mempengaruhinya." Jurnal Akuntansi dan Keuangan 4(1): 17-35.

Heru Perlambang. 2010. "Analisis Pengaruh Jumlah Uang Beredar, Suku Bunga Sbi, Nilai Tukar Terhadap Tingkat Inflasi." Media Ekonomi 19(2): 49-69.

Ilmiah, Jurnal, and Mahasiswa Jim. 2017. "Analisis Investasi Langsung Di Indonesia Maya Malisa 1 * , Fakhruddin 
2 1) 2)." Jurnal Ilmiah Mahasiswa (JIM) Ekonomi Pembangunan Fakultas Ekonomi dan Bisnis Unsyiah 2(1): 116-24.

Ilmiah, Jurnal, Mahasiswa Jim, and Faktor-faktor Yang Mempengaruhinya. 2017. "Analisis Utang Luar Negeri Dan Pertumbuhan Ekonomi: Kajian Faktor-Faktor Yang Mempengaruhinya Salawati Ulfa 1* , T. Zulham 2 1)." 2(1): $144-52$

Indonesia, Republik. 2011. "Presiden Republik Indonesia." (1): 1-9.

Jufrida, Firdaus, Mohd. Nur Syechalad, and Muhammad Nasir. 2017. "Analisis Pengaruh Investasi Asing Langsung (Fdi) Dan Investasi Dalam Negeri Terhadap Pertumbuhan Ekonomi Indonesia." Jurnal Perspektif Ekonomi Darussalam 2(1): 54-68.

Junaidi, Shierly Kusuma, Sri Sulasmiyati, and Ferina Nurlaily. 2018. "Pengaruh Pendapatan Nasional, Inflasi Dan Nilai Tukar Yuan Terhadap Impor Indonesia Dari China Periode 2010-2017." Administrasi Bisnis 60(2): 111-18.

Ma'ruf, A., and L. Wihastuti. 2008. "Pertumbuhan Ekonomi Indonesia: Determinan Dan Prospeknya." Jurnal Ekonomi \& Studi Pembangunan 9(1): 44-55.

Mahriza, Tevi, and Amar Syamsul. 2019. "Pengaruh Investasi Dalam Negeri, Investasi Asing, Tenaga Kerja Dan Infrastruktur Terhadap Perekonomian Di Provinsi Sumatera Barat." Jurnal Kajian Ekonomi dan Pembangunan 1(3): 691-704.

Manuela Langi Theodores ,Masinambow Vecky, Siwu Hanly. 2014. "Analisis Pengaruh Suku Bunga Jml Uang Beredar Kurs Thdp Inflasi Indonesia." 14(2).

Mayo, Regina, Ghozali Maskie, and Devanto Shasta Pratomo. 2014. "Efektivitas Jalur Kredit Dalam Mekanisme Transmisi Kebijakan Moneter Di Indonesia." Jurnal Keuangan dan Perbanakan 18(1): 152-60.

Nuraini, Ida. 2017. "Kualitas Pertumbuhan Ekonomi Daerah Kabupaten / Kota Di Jawa Timur." Jurnal Ekonomi Pembangunan Vol. 15: 79-93.

Samimi, Manouchehr Nouri and Ahmad Jafari. 2011. "The Impact of Monetary Policy on Economic Growth in Iran." Middle-East Journal of Scientific Research 9 (6): 9(6): 740-43.

Secretariat, ASEAN. 2016. ASEAN Statistical Yearbook 2015.

Silvia, E., Y. Wardi, and H. Aimon. 2013. "Analisis Pertumbuhan Ekonomi, Investasi, Dan Inflasi Di Indonesia." Jurnal Kajian Ekonomi 1(2): 7105.

Soleh, Ahmad. 2015. "Pertumbuhan Ekonomi Dan Kemiskinan Di Indonesia." EKOMBIS REVIEW: Jurnal IImiah Ekonomi dan Bisnis 2(2): 197-209.

Sriwardiningsih, Enggal. 2010. "Dampak Pertumbuhan Ekonomi, Suku Bunga, Inflasi, Dan Kebijakan Fiskal Terhadap Investasi Di Indonesia." Binus Business Review 1(2): 307.

Suri, Novia. 2019. "Bab II Landasan Teori." Journal of Chemical Information and Modeling 53(9): 1689-99.

Susanto, Susanto. 2018. "Pengaruh Inflasi, Tingkat Suku Bunga, Dan Nilai Tukar Terhadap Pertumbuhan Ekonomi Indonesia." JEBI | Jurnal Ekonomi Bisnis Indonesia 12(01): 52-68.

Suseno, and Siti Astiyah. 2010. "Seri Kebanksentralan No. 22 - Inflasi." Bank Indonesia 22(22): 1-68.

Yazid, M. 2018. "Inflasi, KURS, Dan Suku Bunga Terhadap Pertumbuhan Ekonomi."Jurnal EKOMBIS 1(1): 3845.

Yuniarti, Puji, Wiwin Wianti, and Nandang Estri Nurgaheni. 2020. "Analisis Faktor-Faktor Yang Mempengaruhi Tingkat Pertumbuhan Ekonomi Di Indonesia." SERAMBI: Jurnal Ekonomi Manajemen dan Bisnis Islam 2(3): 169-76.

Abdullah, G. (2020). Analisis Faktor-Faktor Yang Mempengaruhi Current Account (Neraca Transaksi Berjalan) Di Indonesia. Skripsi. Gorontalo: Universitas Negeri Gorontalo.

Arfiani, I. S. (2019). Analisis Empiris Hubungan Antara Ekspor, Impor, Nilai Tukar Dan Pertumbuhan Ekonomi Di Indonesia. Jurnal Ekonomi Pembangunan, 17(2), 81-98. 
Asnawi, A., \& Fitria, H. (2018). Pengaruh Jumlah Uang Beredar, Tingkat Suku Bunga Dan Inflasi Terhadap Pertumbuhan Ekonomi Di Indonesia. Ekonomika Indonesia, 7(01), 24-32.

Dewi, SP, \& Fasa, Mi (2021). Investasi Dan Inflasi Sebagai Instrumen Pertumbuhan Ekonomi Di Indonesia Dalam Perspektif Ekonomi Islam. Saujana: Jurnal Perbankan Syariah Dan Ekonomi Syariah, 3 (02), 17-32.

Putri, R. P., Heriberta, H., \& Emilia, E. (2018). Pengaruh Inflasi, Investasi Asing Langsung Dan Pengeluaran Pemerintah Terhadap Pertumbuhan Ekonomi Indonesia. Jurnal Paradigma Ekonomika, 13(2), 95-104.

Qoyum, Abdul. (2021). Sejarah Pemikiran Ekonomi Islam. Jakarta: Departemen Ekonomi Dan Keuangan Syariah - Bank Indonesia.

Sari, S., \& Ratno, F. A. (2020). Analisis Utang Luar Negeri, Sukuk, Inflasi Dan Tingkat Suku Bunga Terhadap Pertumbuhan Ekonomi Indonesia Tahun 2014-2019. Jurnal Riset Pendidikan Ekonomi, 5(2), 91-100.

Sopian, A., Ramly, M., \& Arifin, A. (2021). Pengaruh Investasi, Inflasi Dan Tenaga Kerja Terhadap Pertumbuhan Ekonomi Kota Parepare. Paradoks: Jurnal Ilmu Ekonomi, 4(3), 573-582.

Wiriani, E. (2020). Pengaruh Inflasi Dan Kurs Terhadap Pertumbuhan Ekonomi Indonesia. Jurnal Samudra Ekonomika, 4(1), 41-50. 